\title{
Factors Affecting The Selection Of Student Career As A Public Accountant
}

\author{
Merry Susanti, Sofia Prima Dewi, and Sufiyati \\ Faculty of Economics, Universitas Tarumanagara, Jakarta \\ Email:merrys@fe.untar.ac.id
}

\begin{abstract}
The purpose of this study is to determine factors that influence the selection of student career as a public accountant. The data collection method was conducted by distributing questionnaires to Universitas Tarumanagara students. The questionnaire distributed from August to October 2018. Data processing methods were carried out by using partial least square-structural equation modeling (PLS-SEM), which is the contribution of our research, whereas previous research used SPSS as their statistic tool. We also added the motivation variable that not used in the research that we replicate. The data is first tested for its validity and reliability followed by the multicollinearity test, F2 test, adjusted R2, and finally the t test. The results showed that only financial rewards had a positive influence on the selection of student career as public accountants while professional training, professional recognition, social values, work environment, labor market considerations, personality, and self-motivation had no influence.
\end{abstract}

Keywords: choice of student career, financial rewards, professional training, professional recognition, social values.

\section{INTRODUCTION}

Accounting students who have completed a bachelor degree have several choices in determining a career. Accounting students can continue their education to the Master degree and Doctor degree, or they can directly choose a career as employees either in private companies or government agencies. Accounting students have many career choices such as head of the accounting department, head of taxation, accounting staff, tax consultants, financial managers, analysts of accounting information systems, entrepreneurs in various fields of business like services, trading or manufacturing companies, and accountants. Accountants consist of public accountants, corporate accountants, government accountants or educator accountants.

There are many factors that influence the selection of student careers such as financial rewards, professional training, professional recognition, work environment, labor market considerations, social values, and personality. The main objective of accounting students in working besides to obtained financial rewards, is self-development which is gained from professional training and also obtaining professional recognition from the work environment. The work environment and labor market consideration of public accountants are more risky, require time, and pressure than government accountants and educator accountants. 
On the other hand, career as a public accountant is considered as a prestigious career or has social value because the biggest source of income from public accountants has shifted from audit services to management consulting services. The profession of public accountants in Indonesia is far more difficult compared to developed countries such as Australia and the United States. Public accountants in Indonesia must be formally finished their education from undergraduate degree in Accounting, next they must continue their studies by taking Professional Accountant Education (PPAk), and take the Certified Public Accountant exam, as well as experience in providing services at the Public Accounting Office. The increasingly difficult challenges of public accountant careers require the readiness of accounting students to have a professionalism of work and personality.

Research on the factors that influence the choice of students' career as public accountants has been widely carried out, but the results obtained show inconsistency. Those inconsistency research results are shown below:

Table 1. Previous Research

\begin{tabular}{|c|c|c|}
\hline Hypothesis & Hypothesis supported & Hypothesis not supported \\
\hline $\begin{array}{l}\text { Financial rewards have an } \\
\text { effect on student career } \\
\text { selection as a public } \\
\text { accountant }\end{array}$ & $\begin{array}{l}\text { (Rusdiansyah and Ardini, } \\
2017 \text {; Saputra, 2015; } \\
\text { Sinartha and Riduwan, } \\
2014 \text { Suyono, 2014, } \\
\text { Wildiana et al. 2014, and } \\
\text { Yanti } \text { et al., 2014) }\end{array}$ & $\begin{array}{l}\text { (Asmoro et al., 2016; Sari } \\
\text { 2013; and Chan, 2012) }\end{array}$ \\
\hline $\begin{array}{l}\text { Professional training has an } \\
\text { effect on student } \\
\text { selection as a } \\
\text { accountant }\end{array}$ & $\begin{array}{l}\text { (Asmoro et al., 2016; } \\
\text { Saputra, 2015; Sinartha and } \\
\text { Riduwan, 2014; Suyono, } \\
\text { 2014; and Chan, 2012) }\end{array}$ & $\begin{array}{l}\text { (Rusdiansyah and Ardini, } \\
\text { 2017; also Sari, 2013) }\end{array}$ \\
\hline $\begin{array}{l}\text { Professional recognition } \\
\text { has an effect on student } \\
\text { career selection as a public } \\
\text { accountant }\end{array}$ & $\begin{array}{l}\text { (Rusdiansyah and Ardini, } \\
\text { 2017; Yanti et al., 2014; and } \\
\text { Sari, 2013) }\end{array}$ & $\begin{array}{l}\text { (Asmoro et al., 2016; } \\
\text { Sinartha and Riduwan, } \\
\text { 2014; and Suyono, 2014) }\end{array}$ \\
\hline $\begin{array}{l}\text { Social values have an } \\
\text { effect on student career } \\
\text { selection as a public } \\
\text { accountant }\end{array}$ & $\begin{array}{l}\text { (Saputra, 2015; and Suyono, } \\
\text { 2014) }\end{array}$ & $\begin{array}{l}\text { (Rusdiansyah and Ardini, } \\
\text { 2017; Asmoro et al., 2016; } \\
\text { Sinartha and Riduwan, } \\
\text { 2014; Wildiana et al., 2014; } \\
\text { Yanti et al., 2014; and Sari, } \\
\text { 2013) }\end{array}$ \\
\hline $\begin{array}{l}\text { Work environment has an } \\
\text { effect on student career } \\
\text { selection as a public } \\
\text { accountant }\end{array}$ & $\begin{array}{l}\text { (Wildiana et al., 2014; and } \\
\text { Yanti et al., 2014) }\end{array}$ & $\begin{array}{l}\text { (Rusdiansyah and Ardini, } \\
\text { 2017; Asmoro et al., 2016; } \\
\text { Saputra, 2015; Sinartha and } \\
\text { Riduwan, 2014; Suyono, } \\
\text { 2014; Sari, 2013; and Chan, } \\
\text { 2012) }\end{array}$ \\
\hline
\end{tabular}




\begin{tabular}{|c|c|c|}
\hline \begin{tabular}{lll} 
Labor & \multicolumn{2}{c}{ market } \\
considerations have an \\
effect on student & career \\
selection as a & public \\
accountant & & \\
\end{tabular} & $\begin{array}{l}\text { (Mahariani et al., 2017; } \\
\text { Suyono, 2014; Yanti et al., } \\
\text { 2014; and Sari, 2013) }\end{array}$ & $\begin{array}{l}\text { (Rusdiansyah and Ardini, } \\
\text { 2017; Asmoro et al., 2016; } \\
\text { Saputra, 2015; Sinartha and } \\
\text { Riduwan, 2014; Wildiana et } \\
\text { al., 2014; and Chan, 2012) }\end{array}$ \\
\hline $\begin{array}{l}\text { Personality have an effect } \\
\text { on student career selection } \\
\text { as a public accountant }\end{array}$ & $\begin{array}{l}\text { (Rusdiansyah and Ardini, } \\
\text { 2017; Saputra, 2015; } \\
\text { Suyono, 2014; and Chan, } \\
\text { 2012) }\end{array}$ & $\begin{array}{l}\text { (Asmoro et al., 2016; and } \\
\text { Yanti et al., 2014) }\end{array}$ \\
\hline $\begin{array}{l}\text { Self-motivation have an } \\
\text { effect on student career } \\
\text { selection as a public } \\
\text { accountant }\end{array}$ & $\begin{array}{l}\text { (Mahariani et al., 2017; } \\
\text { Arifianto and Sukanti, } 2014 \text { ) }\end{array}$ & - \\
\hline
\end{tabular}

Sourch:

Compare to previous research, this research adds self-motivation from the research of (Arifianto and Sukanti, 2014) with the reason to face increasingly difficult career challenges in addition to work professionalism and personality, of course, which is no less important is self-motivation. In addition, this study uses a different statistical tool, that is partial least square-structural equation modeling (PLS-SEM), while previous studies using SPSS (Statistical Package for the Social Sciences)

\section{THEORETICAL REVIEW}

Motivation-Hygiene Theory. Motivation-hygiene theory is also known as the two-factor theory or pure motivation theory developed by Herzberg. This theory is called the twofactor theory because it consists of two factors, that is satisfaction (motivation) and dissatisfaction (hygiene) in the workplace. Satisfaction factor is an intrinsic factor, which is the drive from within each person that motivates to carry out an activity. The satisfaction factor consists of: opportunities for promotion, opportunities for personal growth, recognition, responsibility, and achievement. Factors of dissatisfaction are extrinsic factors, namely the impulse from outside one's personal, especially from the work environment. Dissatisfaction factors consist of: quality of supervision, salary, company policy, physical condition of work, relationships with other people, and job security (Robbins and Judge, 2014).

(Bangun, 2012) said that satisfaction factors are satisfiers because they can provide job satisfaction for someone and can also improve the performance of workers. However, if this is not fulfilled it does not mean that there is dissatisfaction. The same thing applies to the factor of dissatisfaction. If the factor of dissatisfaction is not fulfilled, it does not mean creating job satisfaction, but only reducing job dissatisfaction. If the satisfaction factor is improved, it will help improve performance, reduce turnover and absenteeism and support a better attitude towards management. Conversely, if the factor of dissatisfaction has been improved by the company, the morale and productivity will increase.

Jurnal Akuntansi/Volume XXIII, No. 02 May 2019: 269-284

DOI: http://dx.doi.org/10.24912/ia.v23i2.588 
(Dessler, 2015) cites Herzberg statement that companies are more interested in creating a self-motivated workforce. This is done by enriching the work so that the work is more challenging and by giving feedback and appreciation to employees. Motivation comes from within a person and motivation will arise only by doing work. Herzberg concluded that relying solely on financial rewards was very risky, so companies should not ignore the benefits of giving formal rewards and challenging work which is the desire of almost everyone.

Selection of Student Career as A Public Accountant. For accounting students, one of the careers that can be chosen is public accountants. According to (Mulyadi, 2013) the profession of public accounting is a profession of public trust. The expectation of the public from the public accounting profession is a free and impartial assessment of information presented by company management in financial statements. This is also emphasized by (Hayes et al., 2014), namely financial statements are the responsibility of company management. Public accountants will increase the usefulness and value of the financial statements of both public and non-public companies also increase the credibility of information issued by company management.

According to (Agoes, 2017) to be able to work as a public accountant in Indonesia, one must first graduate from the Faculty of Economics by majoring in undergraduate degree in accounting to obtain a Bachelor of Economics degree. After that, it will be followed by taking part in the Professional Accountant Education (PPAk) and will get the title of Accountant, then register with the Ministry of Finance to get the accountant's registration number. If a public accountant wants to obtain a practice permit, he must take the Certified Public Accountant (CPA) exam, which is held by the Indonesian Institute of Accountants (IAI) in collaboration with the Ministry of Finance. However, nowadays PPAk graduates no longer directly obtain an Accountant degree. In order to get a Chartered Accountant (CA) degree, they must take the CA exam held by IAI. Those who hold a CA can establish an Accounting Services Office (KJA) after obtaining permission from the Minister of Finance's Center for Financial Professional Development (PPPK).

Financial Rewards. According to (Bangun, 2012) financial rewards are a form of compensation paid to employees in the form of money for the services they contribute to their work. According to (Robbins and Judge, 2014) it is very important to know to what extent the rewards provided by the company can meet individual personal needs and also whether the potential attractiveness of these rewards is attractive to these individuals. (Dessler, 2015) states that not everyone will react the same to financial rewards, and not all financial rewards are suitable for all situations. Managers must understand the motivation underlying the financial reward plan.

(Chan, 2012) in his research argued that students are more interested in choosing a profession as a public accountant because of financial rewards. The more clients held by a Public Accountant Office, the public accountant will be given greater financial rewards compared to other professions. The statement is on accordance with Rusdiansyah and (Ardini, 2017), (Asmoro et al., 2016), and (Yanti et al., 2014). The greater the financial 
appreciation received by a public accountant, the more students will choose public accountant as their profession.

According to (Indriani and Murti, 2018), (Dewayani et al., 2017), (Rusdiansyah and Ardini, 2017), (Yusran, 2017), (Aziz et al., 2016), (Omar et al., 2015), (Saputra, 2015), (Sinartha and Riduwan, 2014), (Suyono, 2014), (Wildiana et al., 2014), (Chairunnisa, 2014), (Yanti et al., 2014) and (Byrne et al., 2012) financial rewards have an effect on student career selection, whereas according to (Wen et al., 2018), (Asmoro et al., 2016), (Aziz et al., 2016), (Sari, 2013), (Chan, 2012) also (Mustapha and Abu, 2012), financial rewards have no effect on student career selection. Thus the hypothesis can be made as follows:

Ha1: Financial rewards have a positive effect on student career selection as a public accountant.

Professional Training. According to (Chan, 2012) professional training includes preparation and training that must be done before starting a career, regular training conducted in the company, training held outside the company, and work experience. A dynamic work environment requires public accountants to take professional training. Professional training provided by the company is a special attraction for public accountants. This is because the challenges faced by public accountants are higher than other accountants.

(Saputra, 2015) stated that students who choose the profession of public accounting require job training to improve their professional abilities in carrying out their careers because public accountants complete their work not only based on formal education but also must be supported by practical experience in the field with adequate working hours. The more professional training offered, the more students will choose the profession as public accountants.

According to (Dewayani et al., 2017), (Yusran, 2017), (Asmoro et al., 2016), (Saputra, 2015), (Sinartha and Riduwan, 2014), (Suyono, 2014), and (Chan, 2012) professional training has an effect on student career selection, whereas according to (Rusdiansyah and Ardini, 2017), (Meliana, 2014), and (Sari, 2013) professional training has no effect on student career selection. Thus the hypothesis can be made as follows:

Ha2: Professional training has a positive effect on student career selection as a public accountant.

Professional Recognition. (Asmoro et al., 2016), (Sinartha and Riduwan, 2014), (Yanti et al., 2014), and (Chan, 2012) stated that professional recognition is related to selfdevelopment and recognition of the achievements of a public accountant in a professional manner. By choosing the profession of public accounting, a public accountant will face various clients who have different problems. Public accountants must use their professional expertise to overcome all these problems. Thus automatically the professional abilities of public accountants will also increase and gain professional recognition for their achievements. With the many opportunities for public accountants to develop themselves in order to obtain professional recognition, more students will choose the profession as public accountants.

Jurnal Akuntansi/Volume XXIII, No. 02 May 2019: 269-284

DOI: http://dx.doi.org/10.24912/ia.v23i2.588 
According to (Indriani and Murti, 2018), (Rusdiansyah and Ardini, 2017), (Yusran, 2017), (Meliana, 2014), (Yanti et al., 2014), (Sari, 2013) and (Byrne et al., 2012) professional recognition has an effect on student career selection, whereas according to (Dewayani et al., 2017), (Asmoro et al., 2016), (Sinartha and Riduwan, 2014), and (Suyono, 2014) professional recognition has no effect on student career selection. Thus the hypothesis can be made as follows:

Ha3: Professional recognition has a positive effect on student career selection as a public accountant.

Social Values. According to (Asmoro et al., 2016), (Saputra, 2015), (Sinartha and Riduwan, 2014), (Suyono, 2014), (Wildiana et al., 2014), (Yanti et al., 2014), and (Chan, 2012) social values show the community's assessment of a person's ability to socialize at work. Humans are social beings, so wherever they are, generally they will socialize with their environment in their homes, workplaces and other places. If a public accountant can interact with people around him, the obstacles he will face in completing his work will also decrease.

As social beings, public accountants must socialize with different client's work environments. If public accountants can socialize, it will automatically be easier to complete their work because public accountants can be accepted in their work environment. Thus the community will view the profession of public accounting as a good profession. The higher the social values of public accountants, the more students will choose the profession as public accountants.

According to (Saputra, 2015), (Meliana, 2014), and (Suyono, 2014) social values have an effect on student career selection, whereas according to (Indriani and Murti, 2018), (Rusdiansyah and Ardini, 2017), (Asmoro et al., 2016), (Sinartha and Riduwan, 2014), (Wildiana et al., 2014), (Yanti et al., 2014), and (Sari, 2013) social values have no effect on student career selection. Thus the hypothesis can be made as follows:

Ha4: Social values have a positive effect on student career selection as a public accountant.

Work Environment. According to (Sinartha and Riduwan, 2014) the work environment is one of the factors that influence employee productivity. The nature of the work in the Public Accountant Office is more time-consuming so it tends to be related to overtime working hours. Job as a public accountant is more attractive. The level of intense competition in the work environment is also felt by public accountants. (Yanti et al., 2014) explained that students who have high competency souls tend to choose a work environment that presents challenges so that satisfaction arises when they can solve the challenges given well. High pressure also exists in the work environment of public accountants, especially with regard to the date line of completion of work. The work environment is one of the factors considered in selecting a student's career as a public accountant.

(Rusdiansyah and Ardini, 2017) in their research stated that a public accountant is required to be willing to work with an intensity of longer time, work harder with a level of intense competition, and a lot of work pressure to produce good work results. The higher 
the challenges in the work environment, the more students will choose the profession as public accountants.

According to (Dewayani et al., 2017), (Omar et al., 2015), (Wildiana et al., 2014) and (Yanti et al., 2014) the work environment has an effect on student career selection, whereas according to (Rusdiansyah and Ardini, 2017), (Asmoro et al., 2016), (Saputra, 2015), (Chairunnisa, 2014), (Sinartha and Riduwan, 2014), (Suyono, 2014), (Sari, 2013), and (Chan, 2012) work environment has no effect on student career selection. Thus the hypothesis can be made as follows:

Ha5: The work environment has a positive effect on student career selection as a public accountant.

Labor Market Considerations. (Suyono, 2014) in his research stated that work that has a broader job market shows that the job profession has job security so that it becomes a consideration for someone in choosing a career. The greater the development opportunity of the work, the greater the chance of the reward to be obtained. (Sari, 2013) explained that career security reflected in a chosen career can last for a long period of time and can continue until someone retires. (Mahariani et al., 2017) and (Asmoro et al., 2016) explained that generally students choose jobs according to the availability of information so that more jobs are available in the future to be considered in choosing a career. The greater the chance of labor market consideration, the greater the desire of students who will choose the profession as public accountants.

According to (Indriani and Murti, 2018), (Dewayani et al., 2017), (Mahariani et al., 2017), (Suyono, 2014), (Yanti et al., 2014), and (Sari, 2013) labor market considerations have an effect on student career selection, whereas according to (Rusdiansyah and Ardini, 2017), (Asmoro et al., 2016), (Lukman and Juniati, 2016), (Saputra, 2015), (Chairunnisa, 2014), (Meliana, 2014), (Sinartha and Riduwan, 2014), (Wildiana et al., 2014), and (Chan, 2012) labor market considerations do not have an effect on student career selection. Thus the hypothesis can be made as follows:

Ha6: Labor market considerations has a positive effect on student career selection as a public accountant.

Personality. According to (Rusdiansyah and Andini, 2017) personality means psychological characteristics from within that determine and reflect how a person responds to his environment. According to (Suyono, 2014) personality shows how to control or reflect a person's personality at work.

(Rusdiansyah and Andini, 2017), (Yanti et al., 2014), and (Chan, 2012) stated that personality is one of the factors that determine individual behavior when dealing with certain situations or conditions. This proves that personality influences a person's behavior. The reason for someone losing their job is due to a personality mismatch with the chosen job. Every person has a different personality because it deals with a person's behavior when in a condition. Accounting students who pursue perfection, demand loyalty, expect recognition of their achievements, enjoy challenges, and accept difficult tasks tend to choose careers as public accountants. The more appropriate the personality of 
a person with the profession of public accounting, students will tend to choose a profession as a public accountant.

According to (Rusdiansyah and Ardini, 2017), (Saputra, 2015), (Meliana, 2014), (Suyono, 2014), and (Chan, 2012) personality has an effect on student career selection, whereas according to (Asmoro et al., 2016) and (Yanti et al., 2014) personality has no effect on student career selection. Thus the hypothesis can be made as follows:

Ha7: Personality has a positive effect on student career selection as a public accountant.

Self-Motivation. According to (Sardiman, 2016), self-motivation is a motive (driving force) that becomes active and its functioning does not need to be stimulated from the outside because from inside of every individual there is an urge to do something. Selfmotivation can also be called internal motivation. According to (Mahariani et al., 2017) self-motivation can be described by a willingness to progress, the ability to take initiative and act effectively, and the ability to face a failure experienced. When accounting students are motivated to become a public accountant, these students will try as much as possible to achieve the career they want.

According to (Mahariani et al., 2017) also (Arifianto and Sukanti, 2014) selfmotivation has an effect on the career choice of students as public accountants. Thus the hypothesis can be made as follows:

Ha8: Self-motivation has a positive effect on student career selection as a public accountant.

\section{METHODOLOGY}

Population and Sampling Method. The population in this study was the accounting student from Universitas Tarumanagara who registered in the odd semester for 2018/2019 who was preparing their final essays. This study uses probability sampling as a sampling method, which means that every accounting student at Universitas Tarumanagara has the same opportunity to be selected as a sample. The sampling technique used was simple random sampling. The size of the study sample was 200 students.

Variable Operationalization. This study consists of dependent variables and independent variables. The dependent variable in this study is the selection of student careers while the independent variables in this study are financial rewards, professional training, professional recognition, social values, work environment, labor market considerations, personality, and self-motivation. Operationalization of variables in this study is measured using several indicators that have been developed.

Data Processing Techniques. The questionnaire was distributed to 200 students and it turned out that the returned questionnaire was 58\% (115 respondents). Next, we use the partial least square-structural equation modeling (PLS-SEM) method in analyzing data by using Smart PLS version 3 software. 


\section{THE RESULTS OF STATISTICAL TESTS}

\section{Test Results for Convergent Validity}

Following are the results of the convergent validity test:

Table 2. Test Results of Convergent Validity

\begin{tabular}{lc}
\hline \multicolumn{1}{c}{ Indicator } & AVE \\
\hline Selection of the career of students as public accountants & 0,507 \\
Financial rewards & 0,755 \\
Professional training & 0,576 \\
Professional recognition & 0,590 \\
Social values & 0,557 \\
Work environment & 0,678 \\
Labor market considerations & 0,609 \\
Personality & 1,000 \\
Self-motivation & 0,565 \\
\hline Sourch.
\end{tabular}

Based on Table 2, all variables can be said to be valid because the value of AVE (Average Variance Extracted) exceeds 0.5. This shows that each indicator of the variable meets the criteria for convergent validity.

\section{Test Results for Discriminant Validity}

Below are the results of cross-loading:

Table 3. Test Results of Discriminant Validity

\begin{tabular}{cccccccccc}
\hline & KM & LK & MD & NS & PA & PF & PK & PL & PS \\
\hline KM4 & 0.761 & 0.154 & 0.231 & 0.364 & 0.295 & 0.544 & 0.391 & 0.208 & 0.216 \\
KM5 & 0.714 & 0.213 & 0.187 & 0.299 & 0.210 & 0.459 & 0.201 & 0.163 & 0.221 \\
KM6 & 0.582 & 0.273 & 0.159 & 0.252 & 0.319 & 0.313 & 0.203 & 0.209 & -0.007 \\
KM7 & 0.775 & 0.232 & 0.042 & 0.473 & 0.322 & 0.476 & 0.291 & 0.249 & 0.215 \\
LK2 & 0.217 & 0.785 & 0.188 & 0.365 & 0.224 & 0.225 & 0.250 & 0.147 & 0.059 \\
LK4 & 0.263 & 0.860 & 0.217 & 0.465 & 0.290 & 0.218 & 0.354 & 0.394 & 0.299 \\
MD1 & 0.070 & -0.008 & 0.624 & 0.216 & 0.329 & 0.118 & 0.166 & 0.199 & -0.028 \\
MD2 & 0.156 & 0.250 & 0.809 & 0.241 & 0.162 & 0.112 & 0.204 & 0.120 & 0.092 \\
MD3 & 0.237 & 0.221 & 0.903 & 0.366 & 0.293 & 0.262 & 0.258 & 0.317 & 0.085 \\
MD4 & 0.082 & 0.203 & 0.634 & 0.254 & 0.112 & 0.094 & 0.213 & 0.260 & 0.152 \\
NS4 & 0.337 & 0.238 & 0.161 & 0.671 & 0.223 & 0.185 & 0.322 & 0.106 & 0.237 \\
NS5 & 0.474 & 0.457 & 0.352 & 0.862 & 0.367 & 0.335 & 0.447 & 0.284 & 0.367 \\
NS6 & 0.259 & 0.451 & 0.302 & 0.691 & 0.476 & 0.265 & 0.367 & 0.454 & 0.292 \\
PA1 & 0.311 & 0.346 & 0.240 & 0.380 & 0.800 & 0.287 & 0.335 & 0.415 & 0.200 \\
PA2 & 0.279 & 0.252 & 0.218 & 0.416 & 0.740 & 0.273 & 0.415 & 0.265 & 0.098
\end{tabular}




\begin{tabular}{llllllllll} 
PA4 & 0.322 & 0.134 & 0.213 & 0.269 & 0.764 & 0.318 & 0.307 & 0.399 & 0.165 \\
PF1 & 0.468 & 0.333 & 0.246 & 0.247 & 0.331 & 0.827 & 0.218 & 0.295 & 0.141 \\
PF3 & 0.629 & 0.160 & 0.151 & 0.359 & 0.336 & 0.909 & 0.345 & 0.286 & 0.215 \\
PK1 & 0.354 & 0.307 & 0.129 & 0.462 & 0.296 & 0.248 & 0.861 & 0.328 & 0.232 \\
PK2 & 0.249 & 0.275 & 0.352 & 0.320 & 0.450 & 0.285 & 0.691 & 0.371 & 0.240 \\
PL2 & 0.222 & 0.248 & 0.156 & 0.221 & 0.211 & 0.253 & 0.429 & 0.738 & 0.119 \\
PL3 & 0.192 & 0.174 & 0.270 & 0.199 & 0.262 & 0.233 & 0.347 & 0.789 & 0.237 \\
PL4 & 0.241 & 0.337 & 0.251 & 0.365 & 0.570 & 0.264 & 0.228 & 0.750 & 0.239 \\
PS1 & 0.246 & 0.231 & 0.103 & 0.405 & 0.203 & 0.210 & 0.298 & 0.261 & 1.000 \\
\hline
\end{tabular}

Sourch:

From table 3, it can be seen that each of the indicators in a variable is different from the indicator in the other variables indicated by the higher loading score in the construct itself. Thus all variables pass the discriminant validity test.

Reliability Test Results. Presented below are the results of loading factor from variables that are used in this research:

Table 4. Loading Factor

\begin{tabular}{cc}
\hline Indicator & Loading Factor \\
\hline KM4 & 0.761 \\
KM5 & 0.714 \\
KM6 & 0.582 \\
KM7 & 0.775 \\
PF1 & 0.827 \\
PF3 & 0.909 \\
PL2 & 0.738 \\
PL3 & 0.789 \\
PA1 & 0.800 \\
PA2 & 0.740 \\
PA4 & 0.764 \\
NS4 & 0.671 \\
NS5 & 0.862 \\
NS6 & 0.691 \\
LK2 & 0.785 \\
LK4 & 0.860 \\
PK1 & 0.861 \\
PK2 & 0.691 \\
PS1 & 1.000 \\
MD1 & 0.624 \\
MD2 & 0.809 \\
MD3 & 0.903 \\
MD4 & 0.634 \\
\hline
\end{tabular}

Sourch: 
From table 4, it can be seen that those indicators have a value of loading factor > 0.4. This results show that the above indicators can be said to be reliable.

Besides using the loading factors of each instrument, reliability can also be seen from composite reliability, which is presented in the following table:

Table 5. Composite Reliability

\begin{tabular}{lc}
\hline \multicolumn{1}{c}{ Variable } & $\begin{array}{c}\text { Composite } \\
\text { reliability }\end{array}$ \\
\hline Selection of the students career as public accountants & 0.803 \\
Financial rewards & 0.860 \\
Professional training & 0.803 \\
Professional recognition & 0.812 \\
Social values & 0.788 \\
Work environment & 0.808 \\
Labor market considerations & 0.755 \\
Personality & 1.000 \\
Self-motivation & 0.835 \\
\hline
\end{tabular}

From table 5, it can be seen that all variables have composite reliability values $>0.7$ so that all variables can be declared reliable.

\section{DISCUSSION}

The following are the results of the $\mathrm{F}^{2}$ test and the $\mathrm{t}$ test for each hypothesis:

Table 6. Test Results of the $\mathrm{F}^{2}$ test and $\mathrm{t}$ Test for

\begin{tabular}{lccc}
\hline \multicolumn{1}{c}{ Variable } & $\mathbf{F}^{\mathbf{2}}$ & $\mathbf{t}$ & $\boldsymbol{\beta}$ \\
\hline Financial Awards & 0.412 & 0.000 & 0.512 \\
Professional Training & 0.001 & 0.776 & -0.029 \\
Professional Recognition & 0.006 & 0.490 & 0.068 \\
Social Values & 0.077 & 0.057 & 0.273 \\
Work Environment & 0.000 & 0.874 & -0.017 \\
Labor market considerations & 0.008 & 0.393 & 0.078 \\
Personality & 0.000 & 0.957 & 0.005 \\
Self-motivation & 0.002 & 0.755 & -0.030 \\
\hline
\end{tabular}

Sourch:

From table 6, it can be seen that the results of the $t$ test are 0,000 with a coefficient of 0.512 which means that financial rewards have a positive effect on the selection of the student career as public accountants. This is also reinforced by the results of the $\mathrm{F}^{2}$ test 
which is 0.412 which indicates that the influence of financial rewards on the career choice of students as public accountants is moderate. Thus Hal is accepted. Many students are interested in choosing a career as public accountants because public accounting firms offer high financial rewards to their employees.

This result is consistent with research conducted by (Indriani and Murti, 2018), (Dewayani et al., 2017), (Rusdiansyah and Ardini, 2017), (Yusran, 2017), (Omar et al., 2015), (Saputra, 2015), (Sinartha and Riduwan, 2014), (Suyono, 2014), (Wildiana et al., 2014), (Chairunnisa, 2014), (Yanti et al., 2014), and (Byrne et al., 2012). However, this study is not consistent with (Wen et al., 2018), (Asmoro et al., 2016), (Aziz et al., 2016), (Sari, 2013), (Chan, 2012) also (Mustapha and Abu Hassan, 2012).

From table 6 , it can be seen that the results of the $t$ test are 0.776 with a coefficient of -0.029 which means that professional training does not affect the selection of the student career as public accountants. This is also reinforced by the results of the $\mathrm{F}^{2}$ test which is 0.001 which indicates that the effect of professional training on student career selection as a public accountant is meaningless. Thus Ha2 is not accepted.

This shows that professional training is not the reason for students to choose careers as public accountants. They consider that professional training can be obtained from various parties not only from public accounting office so that the offer of professional training does not encourage students to choose careers as public accountants. The results of this study are consistent with (Rusdiansyah and Ardini, 2017), (Meliana, 2014), and (Sari, 2013), where they also found no influence on professional training on student career selection as public accountants. However, these results are not consistent with (Dewayani et al., 2017), (Yusran, 2017), (Asmoro et al., 2016), (Saputra, 2015), (Sinartha and Riduwan, 2014), (Suyono, 2014), and (Chan, 2012).

From table 6, it can be seen that the results of the t test are 0.490 with a coefficient of 0.068 which means that professional recognition does not affect the selection of the student career as public accountants. This is also reinforced by the results of the $\mathrm{F}^{2}$ test which is 0.006 which indicates that the effect of professional recognition on student career selection as a public accountant is meaningless. Thus Ha3 is not accepted. This shows that professional recognition is not the reason for students to choose careers as public accountants. They choose careers as public accountants not to obtain professional recognition. In general, people will select career by looking more at whether the career can support his family or not. This causes professional recognition not to encourage students to choose careers as public accountants.

The results of this study are consistent with (Dewayani et al., 2017), (Asmoro et al., 2016), (Sinartha and Riduwan, 2014), and (Suyono, 2014) where professional recognition has no influence on student career selection. This result is not consistent with the research of Indriani and Murti (2018), Rusdiansyah and Ardini (2017), Yusran (2017), (Meliana, 2014), (Yanti et al., 2014), (Sari, 2013), and (Byrne et al., 2012).

From table 6, it can be seen that the results of the $t$ test are 0.057 with a coefficient of 0.273 which means that social values do not influence the selection of the student career as public accountants. This is also reinforced by the results of the $\mathrm{F}^{2}$ test which is 0.077 which indicates that the influence of social values on the career choice of students as public accountants is very small. Thus Ha4 is not accepted. This shows that social values 
are not the reason for students to choose careers as public accountants. They assume that social values are not only obtained from the work environment but can also be obtained outside the work environment. This is because with the development of technology, students can more easily socialize in various environments by using technology, such as whatsapp, line, and other social media applications so that social values do not encourage students to choose careers as public accountants.

The results of this study are consistent with (Indriani and Murti, 2018), (Rusdiansyah and Ardini, 2017), (Asmoro et al., 2016), (Sinartha and Riduwan, 2014), (Wildiana et al., 2014), (Yanti et al., 2014), and (Sari, 2013) where social values have no influence on student career selection. This result is not consistent with (Saputra, 2015), (Meliana, 2014), and (Suyono, 2014).

From table 6 , it can be seen that the results of the $t$ test are 0.874 with a coefficient of -0.017 which means that the work environment does not affect the selection of the student career as public accountants. This is also reinforced by the results of the $\mathrm{F}^{2}$ test which is 0,000 which indicates that the influence of the work environment on the selection of student careers as a public accountant is meaningless. Thus Ha5 is not accepted. This shows that the work environment is not the reason for students to choose careers as public accountants. They consider that the work environment of public accountants is too demanding for long overtime hours and there is also a high pressure on the public accounting profession, so the work environment does not encourage students to choose careers as public accountants.

The results of this study are consistent with (Dewayani et al., 2017), (Rusdiansyah and Ardini, 2017), (Asmoro et al., 2016), (Saputra, 2015), (Sinartha and Riduwan, 2014), (Suyono, 2014), (Sari, 2013), and (Chan, 2012) where the work environment has no influence on student career selection. This result is not consistent with (Omar et al., 2015), (Wildiana et al., 2014) and (Yanti et al., 2014).

From table 6 , it can be seen that the results of the $t$ test are 0.393 with a coefficient of 0.078 meaning that the labor market considerations do not influence the selection of the student career as public accountants. This is also reinforced by the results of the $\mathrm{F}^{2}$ test which is 0.008 which indicates that the effect of labor market considerations on the selection of student careers as public accountants is meaningless. Thus Ha6 is not accepted. This shows that labor market considerations are not the reason for students to choose careers as public accountants. They consider that although there is a large amount of public accountant information available, in reality there are many public accountants who change KAPs or change professions because of attractive financial offers from other parties, so that labor market considerations do not encourage students to choose careers as public accountants.

The results of this study are consistent with (Dewayani et al., 2017), (Rusdiansyah and Ardini, 2017), (Asmoro et al., 2016), (Lukman and Juniati, 2016), (Saputra, 2015), (Meliana, 2014), (Sinartha and Riduwan, 2014), (Wildiana et al., 2014), and (Chan, 2012) where labor market considerations have no influence on student career selection. This result is not consistent with the study of (Indriani and Murti, 2018), (Mahariani et al., 2017), (Suyono, 2014), (Yanti et al., 2014), and (Sari, 2013). 
From table 6 , it can be seen that the results of the $t$ test are 0.957 with a coefficient of 0.005 which means that the personality does not affect the selection of the student career as public accountants. This is also reinforced by the results of the $\mathrm{F}^{2}$ test which is 0,000 which indicates that the influence of personality on student career selection as a public accountant is meaningless. Thus Ha7 is not accepted. This shows that personality is not the reason for students to choose careers as public accountants.

They assume that career selection does not depend on personality, so personality does not encourage students to choose careers as public accountants. The results of this study are consistent with (Asmoro et al., 2016) and (Yanti et al., 2014) where personality has no effect on student career selection. These results are not consistent with the research of (Rusdiansyah and Ardini, 2017), (Saputra, 2015), (Meliana, 2014), (Suyono, 2014), and (Chan, 2012).

From table 6 , it can be seen that the results of the $t$ test are 0.755 with a coefficient of -0.030 which means that self-motivation does not affect the selection of the student career as public accountants. This is also reinforced by the results of the $\mathrm{F}^{2}$ test which is 0.002 which indicates that the effect of self-motivation on the selection of the student career as public accountants is meaningless. Thus $\mathrm{Ha} 8$ is not accepted. This shows that self-motivation is not the reason for students to choose careers as public accountants. They assume that career selection does not depend on self-motivation, so self-motivation does not encourage students to choose careers as public accountants. This result is not consistent with the study of (Mahariani et al., 2017) and (Arifianto and Sukanti, 2014).

\section{CONCLUSION}

The results of this study indicate that students emphasize more on financial rewards in selecting a career as a public accountant. This is indeed undeniable because students after graduation are considered independent. This means that undergraduate students able to earn their own income, no longer financed by their parents. But with the higher cost of living in Jakarta, the students will indirectly pay more attention to financial reward when choosing a career.

\section{REFERENCE}

Agoes, S. (2017). Auditing: Petunjuk Praktis Pemeriksaan Akuntan Oleh Akuntan Publik. Jakarta: Salemba Empat.

Arifianto, F, dan Sukanti, S. (2014). Pengaruh Motivasi Diri Dan Persepsi Mengenai Profesi Akuntan Publik Terhadap Minat Menjadi Akuntan Publik Pada Mahasiswa Prodi Akuntansi Fakultas Ekonomi Universitas Negeri Yogyakarta. Nominal, Barometer Riset Akuntansi dan Manajemen 3 (2): 150-161.

Asmoro, T. K. W., A. Wijayanti, dan Suhendro. (2016). Determinan Pemilihan Karir Sebagai Akuntan Publik Oleh Mahasiswa Akuntansi. Jurnal Ekonomi 1 (1): 164178.

Aziz, D. A., Ibrahim, M. A., Sidik, M. H. J., and Tajuddin M. (2016). Accounting Students' Perception and Their Intention to Become Professional Qualified 
Accountants. SHS Web of Conference The $4^{\text {th }}$ ICGA 36: 1-17. DOI: doi.org/10.1051/shsconf/20173600008.

Bangun, W. (2012). Manajemen Sumber Daya Manusia. Jakarta: Erlangga.

Byrne, M., P. Willis and J. Burke. (2012). Influences on school leavers' career decisionsImplications for the accounting profession. The International Journal of Management Education 10 (2): 101-111.

Chairunnisa, F. (2014). Analisis Faktor-Faktor Yang Mempengaruhi Minat Mahasiswa Akuntansi untuk Berkarir Sebagai Akuntan Publik (Studi Kasus Pada Mahasiswa Ekonomi Akuntansi Universitas Tanjungpura Pontianak). Jurnal Audit dan Akuntansi Fakultas Ekonomi Universitas Tanjungpura 3 (2): 1-26.

Chan, A. S. (2012). Analisis Faktor-Faktor Yang Mempengaruhi Pemilihan Karir Menjadi Akuntan Publik Oleh Mahasiswa Jurusan Akuntansi. Jurnal Ilmiah Mahasiswa Akuntansi 1 (1): 53-58.

Dessler, G. (2015). Human Resource Management. Florida: Pearson.

Dewayani. M. A., C. Chasanah, dan M. S. Anam. (2017). Faktor Yang Memengaruhi Mahasiswa Akuntansi Dalam Pemilihan Karir Sebagai Akuntan Publik. The $6^{\text {th }}$ University Research Colloquium 223-230.

Hayes, R., P. Wallage, dan H. Gortemaker. (2014). Principles of Auditing: An Introduction to International Standards on Auditing. United Kingdom: Pearson.

Indriani, E. and N. W. Murti. (2018). Patterns And Determinants Of Indonesian Accounting Students' Career Choice. Journal of Economics, Business \& Accountancy Ventura $21 \quad$ (2): 207-217. DOI: http://dx.doi.org/10.14414/jebav.v21i2.1438.

Lukman, H., dan C. Juniati. (2016). Faktor Yang Pengaruhi Pemilihan Karir Sebagai Akuntan Publik Bagi Mahasiswa PT Swasta Dengan Pendekatan Reasoned Action Model. Jurnal Akuntansi 20 (2): 202-215.

Mahariani, I. K. I. R., P. G. Diatmika, dan I. P. Julianto. (2017). Pengaruh Motivasi Diri, Persepsi Mengenai Pertimbangan Pasar Kerja Profesi Akuntan Publik, Dan Risiko Profesi Terhadap Minat Mahasiswa Dalam Berkarir Sebagai Akuntan Publik (Studi Empiris Pada Mahasiswa Jurusan Akuntansi Program S1 Universitas Pendidikan Ganesha). E-Journal S1 Akt. Universitas Pendidikan Ganesha Jurusan Akuntansi Program S1 8 (2): 1-11.

Meliana, S. A. (2014). Faktor-Faktor Yang Mempengaruhi Pemilihan Karir Sebagai Akuntan Bagi Mahasiswa Akuntansi (Studi Empiris Pada Mahasiswa Akuntansi Umrah Dan Mahasiswa Akuntansi Stie Pembangunan Tanjungpinang). Jurnal Riset Akuntansi Universitas Maritim Raja Ali Haji Tanjungpinang: 1-23

Mulyadi. (2013). Auditing. Jakarta: Salemba Empat.

Mustapha, M. and M. H. Abu Hassan, (2012). Accounting Students' Perception On Pursuing Professional Examination. International Journal of Education 4: 1-15.

Omar, M.K., A. Zakaria, S. Ismail, J. S. L. Sin, and V. Selvakumar. (2015). Job Selection Preferences Of Accounting Students In Malaysian Private Universities. Procedia Economics and Finance 31: 91-100. 
Ramdani, R. F., dan Zulaikha. (2013). Analisis Faktor-Faktor Yang Mempengaruhi Pemilihan Karir Mahasiswa Akuntansi (Studi Empiris Mahasiswa Akuntansi di Perguruan tinggi di Semarang). Diponegoro Journal of Accounting 2 (4): 1-13.

Robbins, S. P., and T. A. Judge.(2014). Organizational Behaviour. New Jersey: Pearson.

Rusdiansyah, Y., dan L. Ardini. (2017). Faktor-Faktor Yang Mempengaruhi Pemilihan Karir Menjadi Akuntan Publik. Jurnal Ilmu dan Riset Akuntansi 6 (9): 1-22.

Saputra, I. H. (2015). Faktor-Faktor Yang Mempengaruhi Pemilihan Karir Mahasiswa Akuntansi Untuk Menjadi Akuntan Publik Di Perguruan Tinggi Swasta Wilayah Semarang. Jurnal. Semarang. http://eprints.dinus.ac.id/17253.

Sardiman. (2016). Interaksi dan Motivasi Belajar Mengajar. Jakarta: Raja Grafindo Persada

Sari, M. (2013). Faktor-Faktor Yang Mempengaruhi Pemilihan Karir Menjadi Akuntan Publik Oleh Mahasiswa Departemen Akuntansi Fakultas Ekonomi UMSU Medan. Jurnal Riset Akuntansi dan Bisnis 13 (2): 174-201.

Sinartha, B. W., dan A. Riduwan. (2014). Determinan Minat Mahasiswa Akuntansi di Surabaya Terhadap Profesi Akuntan Publik. Jurnal Ilmu dan Riset Akuntansi 3 (2): $1-17$.

Suyono, N. A. (2014). Analisis Faktor-Faktor Yang Mempengaruhi Pemilihan Karir Sebagai Akuntan Publik (Studi Empiris Pada Mahasiswa Akuntansi UNSIQ). Jurnal PPKM II: 69-83.

Wen L., Hongwei (Chris) Yang, Lizabeth Diers, Huaqing Wang. (2018). Public Accounting Vs Private Accounting, Career Choice Of Accounting Students In China. Journal of Accounting in Emerging Economies 8 (1): 124-140. DOI: https://doi.org/10.1108/JAEE-09-2016-0080.

Wildiana, E., T. Taufik, dan V. Diyanto. (2014). Faktor-Faktor Yang Mempengaruhi Pemilihan Karir Profesi Akuntan Publik Bagi Mahasiswa Akuntansi. Jurnal Online Mahasiswa Fakultas Ekonomi Universitas Riau 1 (1): 1-15.

Yanti, N., V. Ratnawati, dan Supriono. (2014). Analisis Faktor-Faktor Yang Mempengaruhi Mahasiswa Akuntansi Dalam Pemilihan Karir Menjadi Akuntan Publik (Studi Empiris Pada Perguruan Tinggi Negeri Dan Swasta di Pekanbaru). Jurnal Online Mahasiswa (JOM) Bidang Ilmu Ekonomi 1 (2): 1-15.

Yusran, RR. (2017). Analisis Faktor Yang Mempengaruhi Minat Mahasiswa Terhadap Pemilihan Karir Akuntan/Non Akuntan. Jurnal Akuntansi (Media Riset Akuntansi \& Keuangan) 5 (2): 203-212. 